CONVERSATION

\title{
Conversation with Maryellen Weimer
}

\author{
Maryellen Weimer \\ Penn State University, Emerita
}

Kwok Pui Lan
Episcopal Divinity School, Emerita

\author{
Thomas Pearson \\ Wabash Center
}

\author{
Eugene V. Gallagher \\ Connecticut College, Emeritus
}

\begin{abstract}
The launch of the new online open access The Wabash Center Journal on Teaching provides the occasion to reflect on the legacy of Teaching Theology \& Religion, which our editorial team has been publishing through Wiley for 22 years. The editors had a conversation with Maryellen Weimer, who has known the journal well through her work on The Teaching Professor (a newsletter published by Magma that provides summaries of articles that appear in disciplinary-focused journals on teaching). Our conversation focuses on how TTR has fit within the broad range of genres and journals that constitute the scholarship of teaching, the value of articles that describe practical teaching techniques (such as our signature Teaching Tactics which will continue in the new journal), opportunities for making research on learning available to busy faculty, and the challenges authors face when contributing to this literature.
\end{abstract}

\section{KEYWORDS}

scholarship of teaching, disciplinary-focused journals on teaching, resources to support teachers, teaching religion, teaching theology, The Teaching Professor

Pearson We happy to speak today with Maryellen Weimer, professor emerita of teaching and learning at Penn State University, whose lifelong work has been disseminating various and sundry materials on teaching and learning, through books, journal articles, and The Teaching Professor newsletter. ${ }^{1}$

Over the years, your articles in The Teaching Professor have called out a number of articles published in Teaching Theology \& Religion (TTR) - the journal our editorial team has been publishing through Wiley since 1997. We're now ending our relationship with TTR to launch a new open access online journal, The Wabash Center Journal on Teaching, where this Conversation will be published in the inaugural issue. I've often forwarded your newsletter to our authors when you've summarized and commented on one of their

\footnotetext{
1 Publications by Maryellen Weimer include Learner-Centered Teaching: Five Key Changes to Practice (2013), Inspired College Teaching: A Career-Long Resource for Professional Growth (2010), Enhancing Scholarly Work on Teaching and Learning: Professional Literature that Makes a Difference (2006), and Improving Your Classroom Teaching (1993). She has edited The Teaching Professor newsletter since 1987. In 2018 the newsletter transitioned to a website. Her popular blog first published as "Faculty Focus" is now a column called "For Those Who Teach." It appears regularly on the Teaching Professor website.
} 
articles, which is a nice boost for them to see that their work was being noticed and commented on. We're curious if you could tell us something about how you discovered the journal, and what you found of value in it? How do you see it fitting into the broader landscape of the scholarship on teaching?

Weimer I've edited the Teaching Professor for over thirty years, and I quickly learned that there are aspects of teaching and learning that are of interest to faculty pretty much across the board. For example, I have yet to find a faculty member who isn't interested in getting more students participating in class, in providing feedback that improves performance, in promoting academic integrity, in wanting more students coming to class prepared - it's a long list of shared interests in teaching and learning. When l'm looking for material to include in the newsletter, I'm after strategies and approaches that can be used with lots of different kinds of course content and ones that are easily adaptable. I'm also looking for strategies that are to some extent based on learning theories or are supported by research.

A lot of the teaching journals today don't focus on instructional strategies, but I think that most faculty have a real love affair with teaching techniques. They can never get enough. For example, I recently wrote about a TTR Teaching Tactic, Reid Locklin's “The (Mostly) Unmarked Quiz” (2019), that fits my criteria: it's a very creative way of using quizzes. A lot of faculty use quizzes to see whether or not students are coming to class prepared. Locklin's quiz accomplishes this, but it does so much more. He promotes deep thinking about quiz answers by facilitating a discussion of them after students have finished the quiz. It's a discussion that requires students to take notes about the various answer options and it's those notes that they're mostly graded on. It's not just a clever strategy. It's based on solid research in cognitive psychology on test-enhanced learning. A strategy like this not only improves performance on exams, it promotes the kind of deep learning necessary for long-term retention.

Kwok Would you say that most journals or publications do not include teaching tactics or actual strategies. Can you tell us why?

Weimer A bit of background can provide context for my answer. I look at about seventy-five to eighty discipline-based pedagogical periodicals on a regular basis. (Many disciplines have multiple journals on teaching.) We've had journals on teaching and learning for a long time. The Journal of Engineering Education and the Lournal of Chemical Education have been published continuously since the early 1900s. But most of the pedagogical journals came into being in the 1960 s or "70s. A lot of them started out as "mom and pop" publications overseen by a faculty member with a strong commitment to teaching. Publication in these journals didn't count for promotion and tenure so faculty weren't expected to write articles. Those who did, wrote because they cared. But the result was scholarship of mixed quality. The easiest articles to write were those that described experiences using a particular teaching technique. It was very much a how-to kind of literature with little or no attention paid to assessment.

When the scholarship of teaching was born in the 1990s, mostly in response to Ernest Boyer's Scholarship Reconsidered monograph (1990), that kind of technique, how-to scholarship was criticized. Many times assessment was a matter of the professor's opinion. Did the technique work? "Yes, it worked! My students really liked it." I'm exaggerating a little bit, but it wasn't particularly robust scholarship. Since then there has been a real move away from articles that report strategies and techniques. If they appear in journals now, they must be assessed in more rigorous ways and that usually means some sort of empirical analysis.

But I think the way TTR has handled techniques in Teaching Tactics is really excellent. They're not presented as articles. They're nice, short pieces that have their own section. You've provided a template that requires authors to respond in several areas. I think that's a great way to share good teaching ideas. It plays well to faculty's ongoing interest in teaching techniques. 
Gallagher When we invented that section we had in mind different ways of giving faculty access to the journal. Teaching Tactics were designed as the lowest barrier and quickest read. Often people say when they get the journal that's the first thing they turn to. You can read them in a couple minutes, and often enough you find something that's useful.

Weimer Yes. If you wanted to push that section a little bit you could have authors include some mention of the learning theory or educational research that undergirds the effectiveness of the Tactic. A lot of faculty think that these techniques work almost by magic. But the good ones do rest on empirical bases - they are evidence-based practices. There are reasons why they effectively promote learning.

Kwok This is a very important issue. Often the authors writing a Tactic or article on teaching may not be knowledgeable about learning theory. They are scholars of religion, but they may not read many theories on teaching.

Weimer I agree. Most discipline-based faculty don't know a lot about learning theory or educational research. But this is an area where I think there is reason for optimism. Starting with Barr and Tagg's article on learner-centered teaching (1995), faculty have been learning about learning. Up until that point faculty focused on teaching. The objective was to improve learning by improving teaching. If you use the components of effective instruction, your students were going to learn better, and there's research that supports the impact of good teaching on learning outcomes. But what's happened since the 1990s, it seems to me, is that the paradigm has really shifted. Pretty much across the board the interest now is in learning and the kind of teaching that promotes it.

Out of that interest in learning and the attention being paid to the learning sciences has emerged the recent interest in evidence-based practice - those strategies and techniques with documentable positive effects on learning outcomes. At this point, if faculty are using or considering use of a particular technique, they want to know if there is evidence to support it. That's the right question to ask, but faculty are looking for straightforward answers and this is social science research so definitive answers are few and far between.

In sum then, most faculty still have a pretty superficial understanding of the science (theory and research) of learning, so I wouldn't expect them to be able to name the learning theory that supports their favorite teaching technique, but l'm hopeful because they're motivated to look for evidence. One thing we know for sure about faculty: they're good at finding evidence and assessing it.

Pearson "Describe the learning principles that undergird the teaching tactic" is a helpful rephrasing for our current prompt "Why is it effective?"

Weimer Yes, but I don't think you want to require a Teaching Tactic author to articulate three learning theories or cite educational research, because then people will stop writing them and as I said, this is a strong section in a journal. Perhaps in this new iteration of the journal it could be expanded. If someone reads and decides to use one of the tactics, could they write up their experience using it? How did they adapt it to their course content? What student response did they observe? Did it have any unexpected benefits? Any advice they might have for others interested in using it? You do need to work to maintain the high quality of the section. It could be a part of the journal that brings even more readers to it.

Kwok You've said that TTR did not include very much educational or psychological theory. Can you say more about how TTR has compared to other journals?

Weimer I'd love to convene a conference of editors of these journals. I don't think there's much communication between them even though their goals are the same and I'm sure they have some of the same struggles. The journals have different strengths and approach things in different ways. There's so much that they could learn from each other. 
One of my suggestions to the three of you as you're making this transition from TTR to The Wabash Center Journal on Teaching, would be to take a look at some of these other journals. I'm very impressed with Life Sciences Education (which used to be called Cell Biology Education). It features some of the very best educational research being done by non-education researchers, most of it's done by biologists of various sorts. The research is strong, well-designed, with interesting analyses, but it's a good example of why faculty don't read educational research. It's not terribly accessible, if you aren't doing educational research. I don't know how many practitioners are reading that journal. If I had to guess, I'd say not many. Now, I do need to point out that Life Sciences Education has a section called Recent Research in Science Teaching and Learning that contains easy-to-read summaries of research on science teaching and learning that is being done in fields other than biology. I'm always finding good material there. I think that kind of section is a great addition to a discipline-based journal.

In terms of quality scholarship, another journal l'd recommend is Scholarship of Teaching and Learning in Psychology. It contains a special feature called the "Teacher Ready Research Reviews." They're reviews of research written for practitioners. They succinctly summarize lots of research and they focus on the practical implications - on what teachers should do, based on the research. There's one that brings together all the research on multiple choice exam questions in an organized, accessible way (Xu, Kauer, and Tupy 2016). There's another that reviews the research that's relevant to accurately interpreting end-of-course rating results (Boysen 2016). Another recent one by Bill Cerbin (2018) says that we should stop arguing about lecturing versus active learning - the fact of the matter is that lecture prevails. It would behoove us to look at the research and discover the ways we can use lectures to promote learning. He explores three areas where the research identifies actions that teachers can take before, during, and after the lecture - that promote better learning from the lecture. It's a wonderful piece.

Other journals that I think are consistently good include Teaching Sociology, Teaching of Psychology, and the Lournal of Management Education. These are well-established journals. The quality of the scholarship is consistently high. And in all of these journals there's work that's relevant in many other disciplines. There's a great study in a recent issue of Teaching Sociology that asks a question of interest to lots of faculty: Do students have to like what they're doing in order to learn from it? (Monson 2019). It's a creatively designed study that looked at students working in groups on research projects.

There are several interesting cross-disciplinary journals as well. For example, the Lournal on Excellence in College Teaching has been edited by by Milt Cox and Laurie Richland for many years. It's published by the University of Miami, Ohio. They publish a nice variety of articles with a good balance between more empirical articles and what I would call personal narrative essays. Teresa Delgado's (2015) metaphor for teaching in TTR, "Good Teaching is like Good Sex," is a great example of a personal narrative essay. I always use it as an example because I get a good laugh when I point out that it's published in a journal on theology and religion. There are also some good topical journals. For example, two British journals, Active Learning in Higher Education and Assessment and Evaluation in Higher Education, which publish lots of good work on those topics.

One of the things that is really interesting when you read all these different journals is the way in which each journal reflects their discipline. The protocols and conventions of the field are frequently superimposed on the study of teaching and learning. One of my favorite examples of this is an article in The Journal of Economic Education that does a cost-benefit analysis of a particular teaching strategy. Given Wabash Center Journal on Teaching's home in religion, I would expect to see fewer quantitative studies. That's not how knowledge is advanced in the discipline. So TTR has been different from other disciplinary journals in that it doesn't preference empirical inquiry. It's like Teaching Philosophy, which publishes exploration kinds of essays, well embedded in the content of the discipline, with advice and suggestions on the best ways to teach content topics like dualism or logic, for example. 
Kwok

Weimer

Pearson

Weimer
What trends do you see in scholarship of teaching today?

I've already implied that much of the scholarly work on teaching and learning is now empirical, some sort of quantitative, qualitative, or descriptive study. You can't get something published in a lot of journals unless it's a study. I think that's too bad, not because I'm opposed to research, but because I think faculty need a range of resources on teaching and learning. I always say that most of us learn how to teach in the school of hard knocks by the seat of our pants. So we all have a very eclectic, individualized knowledge base for teaching and learning. Some of it is real wisdom; some teachers really do come to a good understanding based on their experiences. But faculty can draw some pretty serious misunderstandings from their experiences, so they do need to know more about learning theories and empirical research. But they also need teaching tactics. They really benefit from hearing how different people are handling quizzes, for example, and the feedback mechanisms faculty are using to improve student performance, and how faculty are keeping students' attention in class (and off of their devices). So they need a very pragmatic, how-to stream of literature.

But, they also need essays where faculty are raising challenging assumptions about teaching. My good friend Larry Spence wrote an article called "The Case Against Teaching" (2001) - which is the case for learning. It's an amazingly provocative, stimulating essay. It's the sort of thing that faculty really like to talk about. They need resources that challenge their thinking and their assumptions about teaching. I think they also need inspirational essays. Teaching is an energy draining profession. I think a lot of teachers get tired. They teach a lot and teaching sometimes becomes a relentless grind. They need to be able to read something that reminds them why they do this. The Lournal of Management of Education published a wonderful article by Krista Walck called "A Teaching Life" (1997), written from a mid-career perspective, that asked a lot of questions about what she was doing and why she was doing it. I have given that article to so many faculty; they find it such a source of inspiration.

I don't think that anyone has really cracked the nut in terms of the kind of pedagogical journal that faculty really need. If you look at the history of these journals, the number of faculty who read them is really very small, even though more are reading them now than used to. When I wrote my book Enhancing Scholarly Work on Teaching and Learning (2006), I didn't find a single journal with a subscriber base of more than ten thousand. This was true, even for really large disciplines and disciplines where the price of the journal was partly or totally covered by association membership fees. Now the number of article downloads appear on most journal sites and I'm always amazed that really excellent articles might only have three to four hundred downloads, again, even in very large fields. I think one of the lessons we should have learned by now is that journals are not a particularly effective way of disseminating information about teaching and learning. But the online, open access platform of The Wabash Center Journal on Teaching has lots of potential and makes it possible take the journal in some different directions, including things that you don't see in the more traditional published journals.

That's right. There's the genre of teaching resources that appear on university teaching and learning websites, for example, which could include short videos, how-to slides, or rubrics of one sort or another. These are not a scholarly article, but they may be a valuable resource for teachers.

Yes, exactly. I wish we'd open up the definition of what counts as scholarly. A well-designed assignment and an interesting way of providing students feedback, those can be thoughtfully constructed and written about in ways that I think could be considered scholarly. Our thinking about scholarly work on teaching and learning is too narrow and exclusive, I believe.

What a journal has going for it is scholarly credibility and reputation. Magna Publications has been able to get lots of teachers to read The Teaching Professor. I think we've learned a lot about how to format materials so that faculty will read them. But we're a newsletter, for goodness sake; how can that be scholarly? We have no credibility at all and an article published in The Teaching Professor 
doesn't count in most places because it's not peer reviewed, even though our rejection rates rival those of the best pedagogical publications. You're starting with a well-established journal, making a transition, and I think that gives you the opportunity to push the envelope, to try some new ways of formatting and presenting good content. You're asking the right questions: how do we get busy faculty to read this?

Pearson We're talking about the value of these resources for teachers, but it's occurred to me that an undersung value of the journal is the impact it has on the authors. Requiring them to do the hard work of analyzing the choices they made as they were teaching has a huge impact on them as teachers. Even if no one ever reads their article, I think it's still very valuable for that reason.

Weimer Absolutely. We just published a piece in The Teaching Professor that starts out with the line, "I just received the worst teaching evaluations of my career" (Haave 2019). It's a thoughtful exploration of why and how that happened; the author figured it out, and writing about it was no small part of the solution.

But these personal narratives have great value to those who read them because they are operational models of critical reflection. Donald Schön's work, The Reflective Practitioner (1992), became one of those trendy things in higher education, but I don't think faculty ever understood what it means to really critically think about your teaching. It's a deep, personal confrontation, often with an experience. Those who read see an example of how it's done, but they also learn from the experience. Most faculty do not respond constructively to negative student ratings. Here's an example of different, more constructive way of dealing with not-very-good feedback from students.

Pearson We find that because faculty haven't learned to write scholarship on teaching in graduate school that it's a new genre that we need to teach them how to write. We spend a lot of time coaching authors in this process. Have you done any of this work? Have you helped authors develop articles? How do you go about that?

Weimer Well, it is a labor of love. I find teachers need a lot of encouragement, hand-holding, and editing. They also tend to devalue what they're doing. They've developed really creative ways of getting students to confront how they prepared for an exam with how they performed on the exam. "Oh, you've got to write this up," I tell them. "Nah, it just a simple thing, no big deal. Nobody would publish it."

Shorter writing options, like your Tactic section, can help. But also short essays; publish a prompt or a short scenario and invite seven-hundred-word responses. I think a lot of faculty find writing long, thousands-of-word articles incredibly daunting. They're much more likely to get going with writing if it's a smaller piece. And of course, if it's a smaller piece then the editorial job is a lot less daunting as well.

I haven't looked to see what sort of advice you give authors, but there are some journal websites that include samples of writing in that deadly, passive, academic prose, followed by a contrasting example in a more succinct and discursive style. Side-by-side examples make the differences very clear.

Pearson One strategy l've used that you might find interesting is coaching a potential author who wants to write about a particular teaching experience to adopt the prompts we use for our Teaching Tactics. What is the context? What was your pedagogical purpose? What was the strategy you tried? How did it work and why was it effective? Take those prompts and write a five-thousand-word essay instead of a five-hundred-word Teaching Tactic. It seems to provide them a way to approach an article about teaching.

Weimer Yes, exactly. There could be a kind of query letter that provides a brief synopsis of the topic and then the editors respond with some suggestions as to how it might be developed, or some references to articles they consider examples of how they'd like to see the content formatted. Faculty are good 
at learning from examples. And they're not like students who have a tendency to just copy the examples.

I think faculty worry that if they write in a clear, accessible way, it's too easy and not scholarly. That's a misconception, I think. When I write a seven-hundred-word condensation of a twenty-page research article, I strive for an accurate summary of the study using simple, straight forward language. Believe me, that is an intellectually challenging task. I sweat bullets over those research highlights and I've been writing them for years. They're not easy to write. I think we've forgotten the scholarships of application and integration that Boyer described in Scholarship Reconsidered (1990). It's not the scholarship of discovery, but a different kind of intellectual work. If it's done well, it's scholarly work.

Gallagher Tom, Pui Lan, and I have been running Wabash Center colloquies on writing the scholarship on teaching. We meet for about a week in the first summer, placing participants in writing groups to develop their articles. Then we gather again to review each other's work over a weekend the next winter, and then a final couple of days in the following summer when the articles are completed. Have you had any experience with doing things like that? We keep jiggling around the design of the colloquy to help participants get over the hump of writing about their own teaching.

Weimer I think that's wonderful. I'd love to participate in one of those colloquies. What a great opportunity for peer feedback and real revision. And you're right: Faculty don't talk or think about their teaching in the way writing requires them to do.

I was at a conference a couple months ago and somebody asked the audience, "What's the best thing you've read on teaching and learning?" Of course the first thing mentioned was The Courage to Teach by Parker Palmer (2017), which is truly an amazing book with great content but is also well-written. It has voice, it's personal, but it also has substance. It's a book that makes you think about teaching in ways you never have. Bain's What the Best College Teachers Do (2012) is another example of a superbly well-written book. I think the kind of things that make scholarly writing on teaching and learning readable are not rocket science, meaning they can be learned.

Have you had much success, Gene, with getting people to write good stuff in the colloquies?

Gallagher I think the hardest thing for them is finding conversation partners in the scholarship of teaching. Authors will say, "I've discovered I have this round thing, and if we put four of them on a vehicle the vehicle would move." And we say, "Yes, that's a wheel, and other people have talked about wheels." We have exhausted a lot of energy trying to help people figure out with whom they can be in productive conversation.

Weimer Oh very good.

Gallagher The language that we tend to use is "transferability." Can you reach exit velocity from your own experience in a way that renders it accessible to others so that they can learn from it?

Weimer Yes. There is very little that is new under the pedagogical sun, in my view. It's interesting to me that people continue to publish pieces that claim that something is a new discovery, when it's not. Lots of other people have written about that already. So I think having authors "join a conversation" is a good way to describe it.

Pearson I want to find those "Teacher Ready Research Reviews" you were talking about earlier in the journal, Scholarship of Teaching and Learning in Psychology. It seems they could be a tremendous resource to hand to potential authors to help them find out who their conversation partners might be.

Weimer Yes, absolutely. That's another problem with the discipline-based scholarship: the articles primarily cite other articles in the same journal. They don't cite articles written in other fields. I suppose 
we can't really blame the author. Who has time to read The Physics Teacher if you teach theology and religion? But those of us who care about teaching and learning can do a better job of asking what are the aspects of teaching and learning that transcend disciplines? I think that Lee Shulman (1986) started that a bit by identifying something that he called pedagogical content knowledge. When you're teaching differential equations you want to talk to somebody else who's teaching differential equations so you can get some good problems to demonstrate those equations. But when you're talking about promoting academic integrity, you can talk across the disciplines. If we were better at listing those topics, or those areas, then it seems to me we could border-cross with other fields. Cross-disciplinary collaboration and conversation should be a part of a faculty member's professional development activities. Sometimes it's really good to talk to somebody who teaches something totally different than you do. Not because you're going to do what they do, but because by seeing how knowledge lays out in their field you can understand how knowledge is transferred in your field. I have always worked in this space between disciplines, and it often feels like a no man's land. We're not all that great at border crossing.

Kwok As a final question, how can we encourage faculty to write for the journal when the scholarship on teaching is not generally well-rewarded for tenure and promotion at many institutions, and is often not given high status in the disciplinary guilds?

Weimer I think the scholarship of teaching and learning still counts at some kinds of institutions, but I think that wave has crested. At research institutions and the highly selective colleges, I don't think that scholarly work on teaching and learning counts nearly as much as discipline-based research scholarship does.

Beyond that we still haven't articulated very clear standards of what counts as good scholarly work on teaching and learning. Faculty on promotion and tenure committees aren't used to assessing it and that makes it easy to fall into using disciplinary standards as opposed to thinking about teaching and learning as phenomena in its own right that should be assessed by criteria which are relevant to its own characteristics and features.

But the question was how can you encourage faculty to write when it's not rewarded. The lack of reward and recognition isn't a new phenomenon and that hasn't prevented faculty from doing work in this area. They've been writing about teaching and learning for a long time.

I think you encourage faculty by building on their commitment to teaching and to student learning. If you ask a faculty member, "Are you interested in improving your teaching?" you may not get an enthusiastic response. But if you ask, "Do you care how much and how well your students learn?" it's hard to say no. If you are encouraging people to write about teaching and learning because it's going to improve student learning and improve their effectiveness as a teacher, I think that provides some motivation. If you've got a quizzing strategy and you want to know how and why that works, you're going to learn a whole lot more about it if you spend time writing about it.

Pearson How do you get them to write it, though?

Weimer I think you get them to write it incrementally. You let them write shorter pieces first. You let them write a variety of different kinds of things. You let them be respondents to essays, or curated collections of comments about an essay of some sort. You let them write short reviews. Once people start writing, it can build. I've gotten people going by asking them to explain what they're doing, why, and with what results, in an email. Sometimes it's simply the idea of writing an article that gets in the way. I think having good content in the journal is motivating to people. They want to contribute to something that's good. I think your colloquies are an amazing way to encourage writing. I haven't heard of another discipline trying to encourage writing that way. I think that sounds wonderful.

My thanks to the editorial team at TTR. It was an honor to be invited to do this interview and I've enjoyed our conversation. Best wishes for great success with this new version of the journal. I expect I'll continue to be an avid reader of The Wabash Center Journal on Teaching. 


\section{BIBLIOGRAPHY}

Bain, Ken. 2012. What the Best College Students Do. Cambridge, MA: Belknap Press of Harvard University Press.

Barr, Robert B., and John Tagg. 1995. "From Teaching to Learning - A New Paradigm for Undergraduate Education." Change: The Magazine of Higher Learning 27(6): 12-26.

Boyer, E. L. 1990. Scholarship Reconsidered: Priorities of the Professoriate. Princeton, NJ: The Carnegie Foundation for the Advancement of Teaching. http://files.eric.ed.gov/fulltext/ED326149.pdf.

Boysen, G. A. 2016. “Using Student Evaluations to Improve Teaching: Evidence-based Recommendations." Scholarship of Teaching and Learning in Psychology 2(4): 273-284.

Cerbin, W. 2018. “Improving Student Learning from Lectures.” Scholarship of Teaching and Learning in Psychology 4(3): 151-163.

Delgado, Teresa. “Metaphor for Teaching: Good Teaching is Like Good Sex.” Teaching Theology \& Religion 18(3): $224-232$.

Faculty Focus. 2019. “Faculty Focus.” https://www.facultyfocus.com.

Haave, Neil. July 1, 2019. "My Worst Student Ratings Ever.” The Teaching Professor. Madison, WI: Magna Publications.

Locklin, Reid. 2019. “The (Mostly) Unmarked Quiz: A Successful Classroom Teaching Tactic that Can Be Replicated by Other Instructors." Teaching Theology \& Religion 22(1): 55.

Monson, R. A. 2019. “Do They Have to Like it to Learn from it? Students' Experiences, Group Dynamics, and Learning Outcomes in Group Research Projects." Teaching Sociology 47(2): 116-134.

Palmer, Parker J. 2017. The Courage to Teach: Exploring the Inner Landscape of a Teacher's Life. San Francisco, CA: Wiley.

Schön, Donald A. 1992. The Reflective Practitioner: How Professionals Think in Action. London, UK: Routledge.

Shulman, L. S. 1986. “Those Who Understand: Knowledge Growth in Teaching.” Educational Researcher 15: 4-14.

Spence, Larry. 2001. “The Case Against Teaching.” Change 33(6): 10-19.

Walck, C. L. 1997. “A Teaching Life.” Journal of Management Education 21(4): 473-482.

Weimer, Maryellen. 1993. Improving Your Classroom Teaching. Newbury Park, CA: Sage Publications.

Weimer, Maryellen. 2006. Enhancing Scholarly Work on Teaching and Learning: Professional Literature that Makes a Difference. San Francisco, CA: Jossey-Bass.

Weimer, Maryellen. 2010. Inspired College Teaching: A Career-Long Resource for Professional Growth. San Francisco, CA: Jossey-Bass. 
Weimer, Maryellen. 2018. Learner-Centered Teaching: Five Key Changes to Practice. San Francisco, CA: JosseyBass.

Weimer, Maryellen. n.d. “For Those Who Teach.” Teaching Professor. Madison, WI: Magna Publications.

Xu, X., S. Kauer, and S. Tupy. 2016. "Multiple-Choice Questions: Tips for Optimizing Assessment In-Seat and Online." Journal of Scholarship on Teaching and Learning in Psychology 2(2): 147-158.

JOURNALS REFERENCED IN THE CONVERSATION

Active Learning in Higher Education: The Journal of the Institute for Learning and Teaching in Higher Education (ILT). Thousand Oaks, CA: Sage. ISSN 1469-7874, eISSN 1741-2625. https://journals.sagepub.com/home/ alh.

Assessment \& Evaluation in Higher Education. University of Bath School of Education. Abingdon, UK: Taylor \& Francis Group. ISSN 0260-2938, elSSN 1469-297X. https://www.tandfonline.com/toc/caeh20/current.

Journal of Chemical Education. Washington, DC: American Chemical Society. ISSN 0021-9584, eISSN 1938-1328. https://pubs.acs.org/journal/jceda8.

Journal of Engineering Education. Washington, DC: American Society for Engineering Education. ISSN 10694730, eISSN 2168-9830. https://onlinelibrary.wiley.com/journal/21689830\#pane-01cbe741-499a-4611$874 \mathrm{e}-1061 \mathrm{f} 1 \mathrm{f} 4679 \mathrm{e} 01$.

The Journal of Economic Education. Abingdon, UK: Taylor \& Francis Group. ISSN 0022-0485, e ISSN 2152-4068. https://www.tandfonline.com/loi/vece20.

Journal of Management Education: The Official Publication of the Organizational Behavior Teaching Society. Thousand Oaks, CA: Sage. ISSN 1052-5629, eISSN 1552-6658. https://journals.sagepub.com/home/jme.

Journal on Excellence in College Teaching. Oxford, OH: Miami University. ISSN 1052-4800. http://celt.miamioh. edu/ject/.

Life Sciences Education. Bethesda, MD: The American Society for Cell Biology. elSSN 1931-7913. https://www. lifescied.org/.

The Physics Teacher. Stony Brook, NY: American Association of Physics Teachers. ISSN 0031-921X. https://aapt. scitation.org/journal/pte.

Scholarship of Teaching and Learning in Psychology. Washington, DC: American Psychological Association. ISSN 2332-2101, eISSN 2332-211X. https://www.apa.org/pubs/journals/stl/.

Teaching of Psychology. Thousand Oaks, CA: Sage. ISSN 0098-6283, eISSN 1532-8023. https://journals.sagepub.com/home/top.

Teaching Philosophy. Charlottesville, VA: Philosophy Documentation Center. ISSN 0145-5788, elSSN 2153-6619. https://www.pdcnet.org/teachphil. 
The Teaching Professor. Madison, WI: Magna Publications. ISSN 0892-2209, eISSN 2578-9899. https://www. teachingprofessor.com/.

Teaching Sociology. Thousand Oaks, CA: Sage. ISSN 0092-055X, elSSN 1939-862X. https://journals.sagepub.com/ home/tso.

Teaching Theology \& Religion. Hoboken, NJ: John Wiley \& Sons. ISSN 1368-4868, elSSN 1467-9647. https://onlinelibrary.wiley.com/journal/14679647.

The Wabash Center Journal on Teaching. Crawfordsville, IN: Wabash Center for Teaching and Learning in Theology and Religion. https://www.wabashcenter.wabash.edu/journal/.

\section{AUTHOR BIO}

Maryellen Weimer is a professor emerita of teaching and learning at Penn State Berks and won Penn State's Milton S. Eisenhower award for distinguished teaching in 2005. She has consulted with more than six hundred colleges and universities on instructional issues and regularly keynotes national meetings and regional conferences and has edited The Teaching Professor newsletter since 1987. In 2018 the newsletter transitioned to a website. Her popular blog first published as "Faculty Focus" is now a column called "For Those Who Teach." It appears regularly on the Teaching Professor website. 
